\title{
Coherence Among Street Vendors Act and City Planning Policies Case Study- Patiala
}

\author{
Ajay Kaushal iD \\ Planning and Structural Consultant, A.K. Builders \& Architects, Patiala, Punjab-147001, India \\ ajaykaushal2008@gmail.com
}

ARTICLE INFORMATION

Received: January 29, 2021

Revised: March 04, 2021

Accepted: April 06, 2021

Published Online: June 08, 2021

Keywords:

Coherence, Policy, Street vendor, Informal sector

DOI: $10.15415 / \mathrm{cs} .2021 .82006$ 渵徨

\begin{abstract}
The magnitude of informal sector and its contribution to national economy indicates that $92 \%$ of total work force of 457 million in India, work in the informal sector. Informal sector contributes $60 \%$ to country's GDP (Gross Domestic Product). This sector shares $98 \%$ of the total enterprises in the country. As per 2011 census, Patiala has 4.46 lakh urban population served by 22,000 formal units and 7,000 informal units. Out of these 7,000 informal units, about 2000 informal units fall in walled city. This paper is an attempt to review the coherence among the Street Vendors (Protection of Livelihood and Regulation of Street Vending) Act, 2014 and the City Planning Policies by studying the provisions made by the urban local bodies (ULB) to address the issues of informal sector under this Act and its integration with the city Master Plan before the enactment and after the enactment of the Vendors Act 2014. For better understanding the author has studied the historical evolution of informal trading activities in Patiala, its growth pattern, trend, spatial distribution, socio economic characteristics, space occupied, movement within informal and formal trade and its impacts on traffic, land use and physical environment. Salient features of The Protection of Livelihood and Regulation of Street Vending Act, 2014 have been discussed along with the practical application of the same by Municipal Corporation Patiala and its coherence with the city planning document.
\end{abstract}

\section{Introduction}

India's National Policy on Urban Street Vendor (NPUSV) 2009 was aimed to create an encouraging environment for street vendors to earn their livelihoods, side by side enhancing the environmental conditions in terms of traffic and sanitation (MUEPR, 2009). This policy was unique as it was envisaged to provide a recognition to street vendors on the national level policy framework. It was framed to alleviate the urban poor and to improve their quality of life. The policy was lacking legal background but however in 2014 it gained legal status after the enactment of 'The Protection of Livelihood and Regulation of Street Vending Act 2014'. The co-terminus Twelfth Five Year Plan (Planning Commission, 2013) also speaks of inclusive and sustainable growth. The inclusive growth as defined in Eleventh Five Year Plan is 'a growth process which yields broad-based benefits and ensures equality of opportunity for all'. Therefore sustainable growth is obtained through inclusiveness and equitable distribution of resources to all and this policy is helping for attaining the same.
The street vendors are usually not registered with any department and are covered in the broad umbrella of informal commercial sector. This paper aims to study the position of informal sector in Patiala city before the enactment of the Street Vendors (Protection of Livelihood and Regulation of Street Vending) Act, 2014, the current scenario and coherence of the same in the city planning policies. The author had identified 22 locations ( 8 in walled city and 14 outside walled city) in the city where concentration of informal sector in the form of rehris, roadside sellers, tharas etc. was found to be maximum. Data reveals that the increase in number of urban poor in informal trade has been significant during last three decades in all states of India and in Punjab too. In Patiala also, as per 2011 census, there were 1,500 informal establishments in 1981 , which increased to 2,000 in 1991 , to 3,500 in 2001 and to 7,000 in 2011, which is making a large share of commercial activity in the city. The existence of unplanned informal commercial activities by urban poor, its increasing trends and concentration has adversely affected land uses, transport and physical environment of the area. The focus of the study is 
to find out the inclusiveness of the Act in the city planning policy that is in the Master Plan document before the enactment and after the enactment of the Street Vendors Act 2014.

\section{Character of Patiala City}

The total area of Municipal Corporation of Patiala is 5011 hectares and the total area covered under planned as well as unplanned commercial use is 182.3 hectare which is $2.86 \%$ of the total developed area. Out of this, 39.06 hectare area is under planned commercial, which is $21.43 \%$ of the total developed area. The main unplanned commercial area is confined to walled city. The famous wholesale markets namely Gurmandi, Sher-e-Punjab wholesale cloth market, Medicine market, Timber market, Fruits and Vegetable market, Sarafa bazaar are also located within walled city. The commercial areas within walled city are in the form of line bazaars and lack in parking and other public amenities. There are only two paid parking lots within walled city out of these one is at the back of A.C market and another is opposite to the old Kabari market which are insufficient to meet the demand of present parking. Other than walled city, all the unplanned residential areas have commercial (retail) activity along the main roads.

Table 1: Formal sector Vs informal sector

\begin{tabular}{|l|l|l|l|l|l|}
\hline \multirow{2}{*}{$\begin{array}{l}\text { Sr. } \\
\text { No. }\end{array}$} & \multirow{2}{*}{ Year } & \multicolumn{2}{|l|}{ Patiala City } & \multicolumn{2}{l|}{ Walled City } \\
\cline { 3 - 6 } & & $\begin{array}{l}\text { Formal } \\
\text { Units }\end{array}$ & $\begin{array}{l}\text { Informal } \\
\text { Units }\end{array}$ & $\begin{array}{l}\text { Formal } \\
\text { Units }\end{array}$ & $\begin{array}{l}\text { Informal } \\
\text { Units }\end{array}$ \\
\hline 1. & 1981 & 4775 & 1500 & 1287 & 427 \\
\hline 2. & 1991 & 6250 & 2000 & 1652 & 538 \\
\hline 3. & 2001 & 10900 & 3500 & 2726 & 910 \\
\hline 4. & 2011 & 22000 & 7000 & 5285 & 1766 \\
\hline
\end{tabular}

Source: Census of India, Municipal Corporation of Patiala, Office of the District Town Planner, Patiala (2011)

\section{Evolutionary Process of Informal Trading Activities in Patiala}

Patiala, in pre and during British rule, experienced informal markets and trade as any other city. The steady increase and changes of demographic structure and according to the increasing demands of the population and the physical distance between urban nodes of the city of Patiala have necessitated more than one market centre at different locations. The characteristics of the people and lack of an effective plan perspective have simultaneously caused the origin and growth of informal markets. In this background, the informal commercial sector in Patiala has emerged. The formal shops located at old walled city roads of Patiala city could not develop and got shifted to North-West and South-West parts of the study area. The main reason of which could be attributed to is "accessibility to transport" and "transit" points between two different modes of transport terminals. The informal sector along with formal sector, could thrive well radially to the fort or Quila Mubarak and other parts of walled city. The political influences could also be stated as factors of the present day informal trade.

\section{Growth Pattern and Trend}

The informal traders originated in the centre of the city (study area) and were shifted to North-West and South-West parts. About $25 \%$ of the informal traders are consented in and around fort of walled city and to its adjacent roads in continuity. A few informal traders existed on radial roads or streets around Quila Mubarak in walled city and have been multiplied into 1766 on a normal day and 2190 on festival day eve in 2013 and as per record of Municipal Corporation, Patiala the same increased to 2500 in 2020 . Factors responsible for such a growth pattern of informal traders mainly include accessibility cum transit streets between transport terminals, frequency, formal shops, specialised formal trade and political influences.

\section{Characteristics of Informal Sector in Walled City, Patiala, 2013}

\subsection{Spatial distribution and character of informal sector}

In order to understand the distribution and character of informal sector in the year 2013 that is before the enactment of the Act, a sample size of six vendors of each category (textile, service, household application, perishables, food and allied and others) at each location was taken and the primary survey was conducted by putting questionnaire to the vendors and to the beneficiaries of that locality. That means $6 \times 6=36$ vendors of each location were interviewed 
and making it to total of $(36 \times 8)=288$ vendors. The variations of total number of informal sector vendors of six categories in walled city of identified locations (8 No) are explained in Table 2.

Table: 2: Number of street vendors during festival and non-festival day In Walled City, Patiala, 2013.

\begin{tabular}{|l|l|l|l|l|l|l|l|l|l|}
\hline \multirow{2}{*}{ S. no } & Vending Road & \multicolumn{3}{|c|}{ Non-festival day } & \multicolumn{3}{|c|}{ Day before festival } \\
\cline { 3 - 10 } & & $\begin{array}{l}\mathbf{6 . 0 0} \\
\mathbf{a m}\end{array}$ & $\begin{array}{l}\mathbf{1 0 . 0 0} \\
\mathbf{a m}\end{array}$ & $\begin{array}{l}\mathbf{2 . 0 0} \\
\mathbf{p m}\end{array}$ & $\begin{array}{l}\mathbf{6 . 0 0} \\
\mathbf{p m}\end{array}$ & $\begin{array}{l}\mathbf{6 . 0 0} \\
\mathbf{a m}\end{array}$ & $\begin{array}{l}\mathbf{1 0 . 0 0} \\
\mathbf{a m}\end{array}$ & $\begin{array}{l}\mathbf{2 . 0 0} \\
\mathbf{p m}\end{array}$ & $\begin{array}{l}\mathbf{6 . 0 0} \\
\mathbf{p m}\end{array}$ \\
\hline 1 & $\begin{array}{l}\text { Pilli Sadak Or } \\
\text { Karahwala Chowk }\end{array}$ & 47 & 180 & 265 & 343 & 80 & 250 & 330 & 412 \\
\hline 2 & $\begin{array}{l}\text { Around Fort-Quila } \\
\text { Mubarak }\end{array}$ & 27 & 70 & 137 & 199 & 25 & 110 & 170 & 277 \\
\hline 3 & $\begin{array}{l}\text { Ariya Samaj (Includes } \\
\text { Kacha Patiala And } \\
\text { Triveni Chowk) }\end{array}$ & 32 & 123 & 195 & 289 & 48 & 157 & 230 & 348 \\
\hline 4 & $\begin{array}{l}\text { Lahori Gate \& Its } \\
\text { Radial Roads }\end{array}$ & 39 & 178 & 343 & 453 & 51 & 212 & 377 & 509 \\
\hline 5 & $\begin{array}{l}\text { Kali Temple \& Its } \\
\text { Radial Roads }\end{array}$ & 23 & 46 & 79 & 117 & 53 & 79 & 127 & 153 \\
\hline 6 & $\begin{array}{l}\text { Sheranwala Gate, } \\
\text { Dharampura Bazzar, } \\
\text { Shere Punjab Market }\end{array}$ & 18 & 59 & 87 & 168 & 45 & 91 & 163 & 197 \\
\hline 7 & $\begin{array}{l}\text { Old Anaj Mandi And } \\
\text { Nabha Gate }\end{array}$ & 23 & 54 & 84 & 104 & 27 & 62 & 89 & 137 \\
\hline 8 & $\begin{array}{l}\text { Adalat Bazaar And Its } \\
\text { Radial Roads }\end{array}$ & 15 & 43 & 79 & 93 & 21 & 57 & 104 & 157 \\
\hline & Grand Total & 224 & 753 & 1269 & 1766 & 350 & 1018 & 1590 & 2190 \\
\hline & \begin{tabular}{l} 
Ratio between NFD-FD \\
\hline
\end{tabular} & 1 & 1 & 1 & 1 & 1.56 & 1.35 & 1.25 & 1.24 \\
\hline
\end{tabular}

NFD: Non festival day, FD: Festival day

Source: Survey conducted by author in 2013

\subsection{Socio economic characteristics of informal traders}

The analysis of informal sector of trade and service activities is not only to state the structure and spatial distribution of informal traders but also to portray the socio economic characteristics of the people directly involved in informal trading activities. These characteristics do throw some light on the standard of living of the informal traders.

The qualitative data was collected from primary and secondary surveys by conducting interviews, observations and various documents which was then quantified. The data of socio economic aspects like age, education, gender, occupational background etc. was recorded by the way of interviews and questionnaires.
The other data regarding the timings and frequency of sale, mode of storage, daily income, threats from administration, working hours, facilities and amenities provided was also recorded while interviewing the traders at identified eight locations of each of six categories. The collected data was analysed for each parameter by taking cumulative percentage of each category $(6 \mathrm{No}$.) at each location $(8 \mathrm{No}$.) to the total sample size (289).

The study reveals that about $60.5 \%$ of the traders or vendors are mobile i.e. traders who move about and sell their goods either with or without cart. About $39.5 \%$ traders just squat on the pavement, road margins and sell their goods and commodities. Around 86.2\% traders are between the age of 15 to 60 years, implying that the informal sector trade is operated by the working 
population. Majority of traders are migrant (60.9\% migrants and $39.1 \%$ traders migrated long time back). About two third of the occupation of trader's father occupation was accounted for by agriculture and petty trade, implying that these people are by and large migrants to the city. About $62 \%$ of the traders have been in the informal business or service continuously in the last 15 years. This implies that people in the informal trade continue to live by earning income through informal trading activities. It is almost passed from parents to son or daughter. Less capital (29.2\%), easy to start $(22.2 \%)$, good demand $(9.6 \%)$, learnt from parents or relatives $(22.9 \%)$ are started as reasons for entering into informal sector of trade.

Around $69.9 \%$ of the traders invested between Rs.1000/- and Rs.5000/- in their trading activities. Bicycle (48.8\%) and Rickshaw rehri or Tempo (41.5 $\%)$ is used by the majority of the traders to transport the goods purchased to their points of business. $24.6 \%$ of the traders earn less than Rs.75/-per day and $58.8 \%$ earn between Rs.76-100. About $63.3 \%$ of the traders keep their goods and commodities tied and covered in the same place. All these characteristics imply that the majority of the informal traders are poor and may be living on or below poverty line.

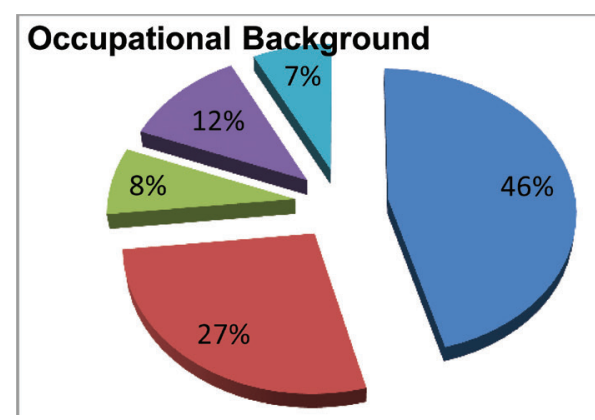

Figure 1: Occupational background of informal sector traders Source: Survey conducted by author 2013

\subsection{Space occupied by informal traders}

Table 3 below gives idea about the extent of space occupied by informal traders and services. On an average, space measuring 24.6 square feet is occupied by one trader. Space occupied by different traders varies and depends upon the type of the trade. Following table shows the extent of space occupied by different traders. Almost two third of traders occupied about 20 square feet and more to carry out their respective activities.
Since the informal traders squat on the pavement and street corner and thus it is objectionable, all informal traders face threats from formal shop keepers and local authorities every now and then. Around 74.8 $\%$ traders work more than eight hours a day, facing competition among the traders themselves and threats from various corners.

Lack of water, public convenience and garbage removal are stated as major problems faced by the traders in addition to the above threats. In order to solve their problems, about $59.4 \%$ traders preferred a common location suitable for business opportunities and $34.2 \%$ traders wanted to have financial assistance.

In regard to the mobility pattern, the experience in the trade is gained from hawking to the formal shop keeping. But the people who are involved in the informal trade are hardly moving towards formal trade. Only $6.9 \%$ of the informal traders have moved to the formal sector from informal sector of trade. Willingness to move is also stated as very poor by informal traders. This again implies that the informal traders are by and largely poor and lack support and assistance to improve their living standards.

\section{- Agriculture \& Allied $\quad$ - Trade \\ - Labour No Job \\ no Response}

\subsection{Income group of beneficiaries}

It was observed and found out from informal traders that a majority of the beneficiaries belonged to upper middle income group and below. Total 48 beneficiaries are randomly picked at different locations identified ( 8 no.) in the study area (walled city). Table 4 gives income groups and gender of respondents in year 2013. 
Table 3: Space occupied by informal traders.

\begin{tabular}{|c|c|c|c|c|c|c|c|c|c|c|c|c|c|}
\hline \multirow{2}{*}{ S.No } & \multirow{2}{*}{$\begin{array}{l}\text { Type of } \\
\text { Trade }\end{array}$} & \multicolumn{12}{|c|}{ Space Occupied in square feet } \\
\hline & & $4 \times 4$ & $4 \times 3$ & $5 \times 3$ & $5 \times 5$ & $2 \times 2$ & $3 \times 3$ & $4 \times 5$ & $2 \times 3$ & $6 \times 6$ & $6 \times 4$ & $6 \times 5$ & Total \\
\hline 1. & Textile & 8 & - & - & - & - & - & 4 & - & - & 4 & - & 16 \\
\hline 2. & Service & 6 & - & 12 & 10 & - & - & 9 & - & 32 & 15 & 7 & 91 \\
\hline 3. & $\begin{array}{l}\text { Household } \\
\text { Application }\end{array}$ & 1 & - & 3 & - & - & - & 2 & - & 12 & 2 & 4 & 24 \\
\hline 4. & Perishable & 8 & - & 6 & 12 & - & - & 26 & - & 10 & 28 & 18 & 108 \\
\hline 5. & $\begin{array}{l}\text { Food and } \\
\text { allied }\end{array}$ & 2 & 3 & 6 & - & - & - & - & - & 4 & 18 & - & 33 \\
\hline 6. & Others & 4 & - & 2 & 8 & - & - & 3 & - & - & - & - & 17 \\
\hline Total & & $\begin{array}{l}29 \\
(10)\end{array}$ & $\begin{array}{l}3 \\
(1.0)\end{array}$ & $\begin{array}{l}29 \\
(10)\end{array}$ & $\begin{array}{l}30 \\
(10.4)\end{array}$ & - & - & $\begin{array}{l}44 \\
(15.3)\end{array}$ & - & $\begin{array}{l}58 \\
(20.1)\end{array}$ & \begin{tabular}{|l}
67 \\
$(23.2)$
\end{tabular} & $\begin{array}{l}29 \\
(10)\end{array}$ & $\begin{array}{l}289 \\
(100)\end{array}$ \\
\hline
\end{tabular}

Source: Survey conducted by author in 2013

Note: Figures in brackets indicate the \%age to total.

Table 4: Income Groups of beneficiaries.

\begin{tabular}{|c|c|c|c|c|c|}
\hline \multirow{2}{*}{ Income range } & \multirow{2}{*}{ Group } & \multicolumn{2}{|c|}{ Number of respondents } & \multirow{2}{*}{ Total } & \multirow{2}{*}{$\%$ age to tota } \\
\hline & & Male & Female & & \\
\hline$<3000$ & EWS & 5 & 4 & 9 & 18.7 \\
\hline $3000-5000$ & LIG & 6 & 3 & 9 & 18.7 \\
\hline $5001-10000$ & MIG & 10 & 7 & 17 & 35.5 \\
\hline $10001-15000$ & MIG(Upper) & 6 & 2 & 8 & 16.7 \\
\hline$>15000$ & HIG & 3 & 2 & 5 & 10.4 \\
\hline \multicolumn{2}{|l|}{ Total } & 30 & 18 & 48 & 100.0 \\
\hline
\end{tabular}

Source: Survey conducted by author in 2013

\subsection{Movement within Informal and formal trade}

A poor migrant or a poor resident of the city becomes hawker, that is he or she carries a head load of items mostly perishable such as vegetables or fruits, goes about the area and sells in first stage. But presently, hawkers are almost obsolete. In the second stage, after having some experience and knowledge about the locality, the trader tries to find the locality where more people gather and starts moving about either with or without a push cart from one location to another depending upon the people's movement. In the third stage, the trader gains some more knowledge about the people's movement and the timing of people's concentration, the trader squats on the pavement or at the corners of the road intersections or in the front of the public buildings such as temple, offices, formal shops, etc. depending upon the availability of space. As the informal trader sustains by gaining and familiarised with the location, the informal trader starts in the fourth stage putting up the petty shop or bunk stall on the pavement or by renting a small shop. As the informal sustains further and earns well, he in the fifth stage either widens the shops or move to a bigger shop and thus begins to enter into a formal shop. In the process, some of informal traders enter into the formal shops or trading houses as salesman before starting a petty informal way or going back to the informal trade.

There are various factors responsible for the movement of traders with in the informal sector and between the informal and formal sector. The important factors are age, tactics and skills of trader, trader's personal and family commitments, aspirations of traders, opportunities and organisational efforts.

In order to have an idea of the actual mobility, the trader of the informal sector in sample was asked to give 
to the best of his or her knowledge about the present and past of his/her career and also about other traders known to him or her. A few sales man in the formal shops were also interviewed informally. By this way, it is ascertained that as a whole $5 \%$ of the sample traders had an experience of hawking before vending experience, before squatting and selling in permanent place.

Only $6.6 \%$ of the traders particularly from service, perishable and food allied activities have shifted to formal sector of trade. Almost $93.5 \%$ of the informal sector traders are satisfied and continue to improve their trade through informal trading activities. The potential mobility from informal to formal sector is also very low (around 6.6\%) which is revealed by the field data. The possible cause for the lack of interest in the informal traders to move to formal sector is partly because of the capital required and partly that formal sector cannot be entered 'just like that'. Thus the field data and qualitative information shows that there is little mobility both actual and potential from informal to formal sector. Perhaps the people who take up informal trade decide to stay on and earn through moving within the informal sector in their life time. It is noticed already that about one third of the traders father's occupation was petty and informal trade.

\section{Impacts of Informal Sector of Trade}

The informal sector of trade, with or without formal sector, brings about its impacts on the traffic and transportation, land use and land values and the physical environment. The impact of informal sector of trade is pertinent to traffic and transportation because the informal traders squat on pavements and road margins and junction corners to do their business, forcing the pedestrians to walk on the carriage way which in turn effects the traffic flow on the carriage way and brings in accidents as well. In the study area of old walled Patiala city, the carriage ways are effected and are reduced to almost nil or one third of their width have been made one way. The existence and the encroachment of informal traders in busy streets of the study area and the accidents that have occurred on these roads are somehow related.

The traffic jams and slow vehicular movement due to the reduction of carriage way have become the cause of air pollution, noise pollution and nuisance to the public in that particular stretches of the roads. The informal traders in perishable goods and commodities deteriorate the land and water. All these impacts are essentially negative and are severe on festival days and does not seem to be positive of the impact.

Commercial activities do indeed effect changes in the land use of the area, as they are likely expanded through the time and space. Multiplication of informal traders and their movements expedite the changes. The increase in the formal and informal traders, as this study indicates, in last 3 decades in general and in period 2001 to 2011 (In year 1985, area under commercial activities was 116.13 acres, about 250 acres was in 2000 and 450.28 acres was in 2001-2011) in particular has increased the lands under commercial uses. As a result, the demand of land for commercial uses has increased the value of the land.

As the changes occur in land uses and values through the space and time, the authorities concerned for regulating the land in cities are forced to take up new stock of land uses and revise their land use zones from residential to mixed residential land uses, commercial land uses, and sparsely built up areas to continuously built up areas, etc. These changes due to increased commercial activities constituted by formal and informal trade activities have been made use of as sources of modifying the detailed development plans, land use zones and traffic management of the business areas. Yet, the informal traders and trading activities which are the main sources of effecting the changes in traffic, land use and physical environment, are left untouched without incorporating them as part of the physical planning in Patiala and no such revision of Master Plan or preparation of zonal plan has been done in this regard.

\section{Informal Sector of Trade and City Development}

In the process of economic development and development of the human settlements, particularly in the developing countries like India, the working population available of informal sector in both urban and rural areas is larger than that of the formal sector of economy. The labour released from the subsistence sector, surplus population from the rural areas and the natural increase in the urban population are the factors responsible for the rapid growth of urban population in developing countries (Naik, 2009). A large number of this urban population remains unemployed and under-employed. 
In this context, as the formal sector of economy fails to generate adequate and diversified employment opportunities to the size of the population growth rate, the unemployed and under-employed personsmen, women and children have to find source of their living (Kapoor et al, 2009). The sources these people find from time immemorable were manufacturing of certain items and selling them in informal ways. Later these people started buying the goods and commodities readily available in the market and selling them directly to the people. Thus came the informal traders and services in the cities. This way the informal sector is not new and is very much linked to the consumable sector of the city economy on another.

The informal sector of trade and services has backward linkage with the formal sector in the form of buying of the inputs such as raw materials, marketable goods and commodities. It is a fact that the informal traders sell their goods directly to the certain section of the urban population which is by and largely constituted by the vast majority of low income groups. Its linkages with the formal sector to sell their commodities is almost nil. Thus, the informal sector of trade caters its service to the city population and develop in the terms of fulfilling the demands of the consumable items of the urban population. The existence of the informal sector of trade does indeed contribute to the physical growth and expansion of the commercial areas in the city vertically and horizontally.

\section{Legal framework (Vendor's Policy and Act)}

The discussion on various platforms on the informal sector of economy consisting of manufacturing, trade and services has been around the question of policy decisions towards this sector. It is well argued and discussed that it has high potential for growth of informal sector of manufacturing and potential for incorporating of informal sector of trade and service in physical planning of human settlements, as it, progressively plays a vital role in economic development. Yet it has not received positive response from the authorities concerned. Not only this, it continues to face threats from various angles every now and then and from nature as well. In order to overcome these threats the National Policy of Urban Street vendors, 2004 was framed by Government of India.
Vendor's issues were visible in this policy. The policy aimed to provide confined and properly designed hawking zones with some facilities enhancing the quality of life of vendors, to deliberately avoid using public spaces and to make street vendors a special component of the urban development or zoning plans. Later on the 2004 policy was revised as "National Policy on Urban Street Vendors, 2009". Many practical issues related to street vendors like registration procedures and fees, revenue collection, eviction, relocation, public health and hygiene, self-regulation, credit and insurance, rehabilitation of child vendors, education and skill development, housing, social security, monitoring and review, dispute settlement and capacity building were elaborately addressed. But still the policy was lacking legal status and in 2014 The Street Vendors (Protection of Livelihood and Regulation of Street Vending) Act, 2014 was enacted, which was aimed to regulate street vendors in public areas and protect their rights. The act stresses on formation of a Town Vending Committee chaired by Commissioner Municipal Corporation and members from other government and non-government departments and organisations like street vendors associations, traders associations, non-government organisations, community based organisations, resident welfare organisations and banks etcetera, who will collectively ensure that all the street vendors identified in the survey are accommodated in the vending zones.

The chapter four of the Act suggests preparation of a vending plan on the recommendation of Town Vending Committee once in every five years, which is to be prepared by the local authority in consultation with planning authority. The vending plan shall ensure that all the street vendors identified in the survey have been accommodated in the plan for street vending and the civic facilities for appropriate use of vending zones have been incorporated. The plan should determine the restriction-free-vending zones, restricted vending zones and no-vending zones and also contain the consequential changes in the existing Master Plan, Development Plan, Zonal Plan or any other plan to be prepared for accommodating the street vendors in the vending zones. The state government shall frame a Street Vending Scheme in consultation with Town Vending Committee and the local authority within six months from the date of commencement of this Act and notify the same in the official gazette. 
Section 38 of the Act is about the preparation of a Street Vending Scheme by the state government in consultation with Town Vending Committee and the local authority within six months from the date of commencement of this Act for systematic implementation of the Act by mentioning the manner of conducting survey, the terms and conditions regarding issuing certificate of vending, identity cards, the vending fees, its renewal, manner of collecting vending fees, maintenance charges, relocation of vendors, eviction etc.

\section{Status of enactment of the Street Vendor's Act in Punjab}

The Punjab Street Vendors (Protection of Livelihood and Regulation of Street Vending) Rules were notified by the Punjab Government on $12^{\text {th }}$ February 2015. Manner of constitution, term and the members of Town Vending Committee were defined in these rules as per section 22, 23, 34, and 36 of the Vendors Act. On $3^{\text {rd }}$ March 2016 the Punjab Street Vendors (Protection of Livelihood and Regulation of Street Vending) Scheme was notified by as per section 38 of the Street Vendors Act. The manner of conducting surveys and the time frame for its implementation has been mentioned in the scheme along with the time period, terms and conditions and eligibility criteria for issuing the certificate of vending. The vending fees, manner of collecting vending fees, categories of street vendors, manner of shifting street vendors to alternate sites and manner of eviction have been elaborated along with a mention of norms for up-keeping public health and hygiene and record maintenance of Street Vendors. The scheme speaks of not any "no restriction free vending zone" and a minimum of "no vending zone" in the city. The other issues like holding capacity of vending zones and terms and conditions of vending have also been mentioned in the scheme.

\section{The Street Vendor's Act: Present status and its coherence with Master Plan Patiala}

After the notification of the Punjab Street Vendors (Protection of Livelihood and Regulation of Street Vending) Scheme, the Street Vending Committee was established in May 2018 in Patiala. The committee hired a Chandigarh based consultant in December 2018 for the systematic implementation of the Act. A total of 4025 street vendors have got registered themselves in the office of Municipal Corporation, Patiala. Out of these, 2076 street vendors are stationary, 510 are mobile, 808 vendors are Sunday market vendors and rest 631 are other weekly market vendors. As per survey conducted in the year 2013, the data reveals that only two third $\left(2 / 3^{\text {rd }}\right)$ of street vendors are registered with the local authorities, therefore the actual number of street vendors would be around 6000 in the Patiala Municipal Corporation. The consultant had identified 28 locations and five vending roads (approximately 2500 metres in length) in the city to accommodate these vendors initially, but since, he was not a local resident of the city, therefore some of the pockets identified for street vending by the consultant were not feasible and therefore were not considered for practical implementation of the project. In the first phase, a Vending Plan has been prepared to accommodate 520 vendors which are to be relocated to Sanauri Adda area of Patiala. The project was inaugurated on $14^{\text {th }}$ August 2019, but delayed by almost one year. In September 2020 , Identity cards were issued to the registered street vendors, but many left for native places due to COVID pandemic. In nutshell, after seven years of enactment of the Street Vendors (Protection of Livelihood and Regulation of Street Vending) Act, 2014, no concrete development has been noticed in the city.

As per section 21 of the Street Vendors Act, 2014, the Street Vending Committee should notify a vending plan accommodating all the vendors identified in the survey and should earmark vending zones as per the space available close to the existing markets. But, in Patiala case as discussed above only 520 vendors out of 4025 have been proposed to be accommodated in the vending plan and that too after seven years of enactment of the Vendors Act.

Moreover as per first schedule of the Act, the spatial planning norms for street vending have not been incorporated in the vending plan, neither the consequential changes which are required to be done in the existing Master Plan or Zonal plan have been done till date, which could help in creating a coherence among the city Master Plan and Vendors plan. Since, the City Master Plans in Punjab are prepared by the Department of Town and Country Planning under the umbrella of Department of Housing and Urban Development, Punjab. For any such kind of amendment or updation, the same needs 
to be communicated to the Department of Town And Country Planning, being the custodians of Master Plans, but no such communication till date has been done by the Department of Local bodies, Punjab to Department of Housing and Urban Development for making the vendors plan coherent to the city Master Plan and preparing or updating the zonal plans.

\section{Conclusions}

National Policy on Urban Street Vendor (NPUSV) was framed in the year 2009 to improve the quality of life of urban street vendors and to give them a recognition on the National level. The Master Plan Patiala was prepared in the year 2009-2010 and was notified on 23-8-2010, but unfortunately the document could not address the issues of informal sector and urban street vendors. Later on the policy was given a legal status and The Protection of Livelihood and Regulation of Street Vending Act, 2014, was enacted by Government of India. With a very slow pace, The Punjab Street Vendors (Protection of Livelihood and Regulation of Street Vending) Scheme was notified by Government of Punjab in the year 2016 and the vending committee was formulated in the year 2018 in Municipal Corporation Patiala as per the provisions of the Act. A Vending Plan accommodating 8-10\% of street vendors has been prepared by Municipal Corporation Patiala in isolation. No detailed vending plan for accommodation of all the street vendors and showing the spatial planning norms for street vending has been prepared till date. The zonal plan showing the proposed changes for the proposed locations in the present Master plan has not been prepared yet and neither been conveyed to the Department of Town and Country planning, which shows a lack of coordination between the two planning agencies working in Patiala. As a result, the urban poor is been deprived of being part of inclusive planning and the objective of integrated planning approach is not achieved.

\section{References}

Bhowmik, S.K., (2003). National Policy for Street Hawkers. Economic and Political Weekly, 38(16), 1543-1546. Retrieved September 18, 2020, from https://www. epw.in/journal/2003/16/commentary/nationalpolicy-street-vendors.html
Chakraborty, P., \& Koley, S. (2018). Socio-Economic View on Street Vendors: A Study of a Daily Market at Jamshedpur, Journal of Advanced Research in Humanities and Social Science, 5(1), 14-20.

Kapoor, R., Krishnapriya, P.P. (2019). Explaining the contractualisation of India's workforce. ICRIER. Retrieved October 07, 2020, from https://icrier.org/ pdf/Working_Paper_369.pdf

Naik, A.K. (2009). Measuring the Informal Economy in Developing Countries: Informal Sector and Informal Workers in India. IARIW-SAIM Conference. Retrieved October 10, 2020 from http://iariw.org/conferences/ past-conferences

Ministry of Urban Employment and Poverty Alleviation, Government of India (2009). National Policy on Urban Street Vendor. Retrieved from https://www.prsindia. org/sites/default/files/bill_files/bill82_2006123082_ National_Policy_for_Urban_Street_Vendors.pdf

NSSO (2012). Informal Sector and Conditions of Employment in India Report No. $539(66 / 10 / 2)$. Accessed on 4 December 2020 at website http://mospi.nic.in/sites/ default/files/publication_reports/nss_rep_539.pdf

Planning Commission, Government of India (2013). Twelfth Five Year Plan (2012-2017), Sage Publications. Retrieved December 04, 2020 from http://niti. gov.in/planningcommission.gov.in/docs/plans/ planrel/12thplan/pdf/12fyp_vol1.pdf

Sharma, S. (2016). Hawking Space and National Policy on Urban Street Hawkers: A study of NDMC, Delhi. Procedia Technology, 24, 1734-1741. https://doi.org/10.1016/j.protcy.2016.05.207

Singh, A.K. (2010). Inclusive Urban Development in India, Background Paper, RCUES, Lucknow. Retrieved December 05, 2020, from http://rcueslucknow. org/publication/TrainingModules/Dr.A.K.Singh/ InclusiveUrbanGrowth.pdf

The Punjab Street Vendors (Protection of Livelihood and Regulation of Street Vending) Rules, 2015 (Pb). Retrieved June 10, 2020, from http://mohua.gov.in/ upload/uploadfiles/files/13(1).pdf

The Punjab Street Vendors (Protection of Livelihood and Regulation of Street Vending) Scheme, $2016(\mathrm{~Pb})$. Retrieved June 10, 2020, from http://gpunjab.gov.in/ upload/582473265ce38StreetVendorsScheme.pdf

The Street Vendors (Protection of Livelihood and Regulation of Street Vending) Act, 2014, published in the Gazette of India by Legislative Department, Ministry of Law and Justice on 05 March 2014. Retrieved June 10, 2020, from http://www.egazette. nic.in/WriteReadData/2014/158427.pdf 


\section{旬 \\ CHITKARA}

\section{Creative Space}

Chitkara University, Saraswati Kendra, SCO 160-161, Sector 9-C, Chandigarh, 160009, India

Volume 8, Issue 2

January 2021

ISSN 2321-3892

Copyright: [C 2021 Ajay Kaushal] This is an Open Access article published in Creative Space (Creat. Sp.) by Chitkara University Publications. It is published with a Creative Commons Attribution-CC-BY 4.0 International License. This license permits unrestricted use, distribution, and reproduction in any medium, provided the original author and source are credited. 